\title{
NASA og Google Travels
}

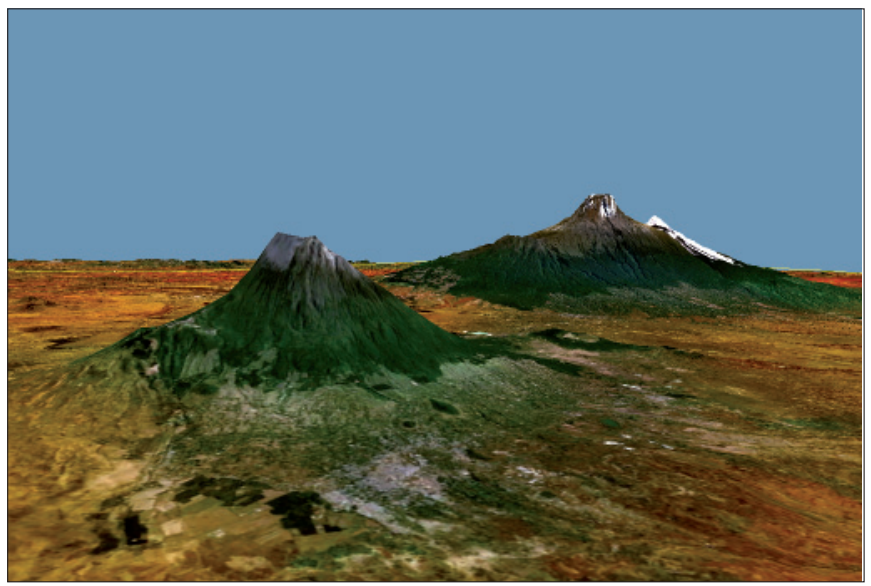

Flyvetur over vulkanen Kilimanjaro. (www.worldwind.arc.nasa.gov/)

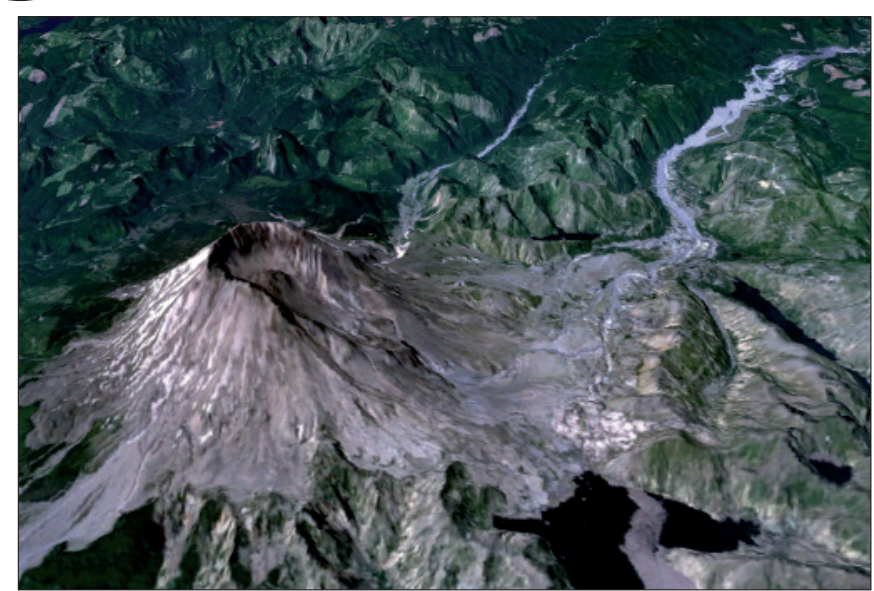

Mt. St. Helen i Rocky Mountains i USA. (www.earth.google.com/)
Af GeologiskNyts webmaster geolog Steen Laursen

Var det noget med en billig ferie Jorden rundt? Bare et par timer en formiddag? Hvis geologi og især vulkaner er selve pointen, så vil jeg da varmt anbefale en vinterferie med NASA's World Wind og Google Earth. Programmerne giver en flot jordomrejse på internettet, $\mathrm{og}$ de har hver deres fordele.

Så er de andre syge eller taget på vinterferie. Eller begge dele. Jeg har æren af at blive hjemme og passe biksen, så min rejse må jeg klare i dag mellem 9:30 og 12:00. Kunderne er sikkert på ferie alligevel.

NASA Travels foreslår en pc-ferie på ægte virtuelle vulkaner, og den starter i Afrika. Det er en fristende mulighed, for det ser faktisk ud til, at der har været et vulkanudbrud i den dér østafrikanske sprækkedal.

\section{Flotte landskaber i Østafrika}

Flyveturen til den afrikanske vulkan er flot. Fra en højde af mange tusinde kilometer dykker vi direkte ned mod en stor sø med høje bjerge omkring. Dykket ender over den sydlige ende af søen, og så flyver vi lavt hen over vandet mod nord og ser vulkanen vokse op af søens bred. Vi suser op over bjergene mod øst og efter en kort flyvetur over en håndfuld små vulkaner, tårner selve
Afrikas største vulkan Kilimanjaro sig op foran.

Markerne fortsætter helt hen til bjergets fod, men op ad flankerne vover de sig ikke. Selv når man frister skæbenen, skal man jo ikke ligefrem læne sig op ad en øretæve. I følge Google Travels har National Geographics være på besøg. De har lavet en usigelig mængde af farvestrående billeder og artikler om folk, vulkaner og den stegende, knastørre vind.

\section{Raserede bjerge i Nordamerika}

Næste vulkan på turen er Mt. St. Helen i Rocky Mountains i USA. Det er den, der eksploderede med et ordentligt knald for føje år siden. I dag ser den stadig ud som en fæl dagen-der-på. Hele den ene flanke er sprængt bort, og landskabet er noget sandblæst at se til. Der er faktisk kun planter på læsiden af nabobjergene. "St." betyder vist helgen, men den her er ikke en af de blide. Google Travels har også denne vulkan på programmet. De har en fortegnelse over hundrede og sytten jordskælv og fantastiske nærbilleder.

46 minutter og en stribe voldsomheder inde i min pc-ferie dykker vi ned imod Manam, som er eksklusiv for NASA's katalog. Som navnet antyder, er det en helt anderledes indbydende vulkan, men så ligger den også ud for Papua Ny Guinea. Her er vandet mørkeblåt, kysterne frodige og stranden har friske, hvide bølgesprøjt. Hvis jeg ser en af mine "syge" kolleger dernede, sladrer jeg til chefen.

\section{Storbyferie}

Chefen er for resten i New York. Hans ferie kan man da også lige kigge til. På storbyer er Google Travels klart førende. Et dyk direkte ned mod Manhattan viser, at amerikanerne ikke gør meget i små kone-biler og de holder sig til sort, hvid og alarmrød. Googles specialitet her er en svingtur imellem 3D skyskraberne, så Spiderman må blive rød og blå af misundelse. Rejseselskabet her viser også, hvor der er hoteller, men det bliver vist svært at finde chefens i vrimlen. Nå, han hygger sig sikkert fint alene.

\section{Aktiv vulkan i Sydamerika}

Men så er der jo også vulkanudbrud i Tungurahua i Sydamerika, og selv om det stod på 14. januar 2004, så er det med i NASA's pc-rejse. I kanten af en imponerende bjergkæde, som er marmoreret af dybe, flodskabte kløfter, rejser vulkanen sig over en smukt meandrerende flod. En tæt sky af aske og gas fra vulkanens krone breder sig ud til et flortlet klæde, som driver ind over bjergene.

Jeg tror, jeg vi udleverer adressen på de to rejsebureauer her til dig, for det er sjovere at rejse flere sammen. Google Travels finder du på: http://earth.google.com/

\section{Og NASA Travels er på:}

http://worldwind.arc.nasa.gov/ Skulle du blive træt af små jordiske vulkaner, så kan NASA også sende dig op til Månens meteorkratere. Og så skal du i øvrigt lige huske, at alle rejserne er bedst på en rigtigt stor bredbåndsforbindelse, og computeren skal heller ikke være en af de små. 